\title{
Rheumatoid factor in cases of rheumatic fever and parasitic infestation in children
}

\author{
Z. H. ABDIN, M. A. M. ABUL FADL, AND S. EL-FIL \\ From the Pyramid Rheumatic Heart Centre and Cairo Research Institute, Egypt
}

The incidence of rheumatoid factor in inflammatory disorders of connective tissue, particularly rheumatoid arthritis, has been discussed by Ziff (1957), Black, Goldin, Poske, and Malmed (1959), Bywaters, Carter, and Scott (1959), Kellgren and Ball (1959), Dixon (1960), and Hill and Greenbury (1965), and in other rheumatic and non-rheumatic diseases by Ziff (1957), Kellgren and Ball (1959), and Bartfeld (1960).

There have been few reports of its incidence in rheumatic fever and its occurrence in parasitic infestation has not been investigated, Both rheumatic fever and parasitic infestation are highly prevalent among children in Egypt, and a study on the incidence of rheumatoid factor in these conditions is now reported.

\section{Material and methods \\ The following patients were investigated}

\section{GROUP I}

(A) 142 patients diagnosed as cases of rheumatic fever with polyarthritis, satisfying the modified criteria of Jones (1955), viz. a major criterion (polyarthritis) together with two or more minor criteria, such as fever and a raised erythrocyte sedimentation rate. They also all had significant murmurs indicative of an organic valve lesion as well as a previous sore throat. Their ages varied from 6 to 16 years.

(B) 27 patients with quiescent rheumatic heart disease.

\section{GROUP II}

64 children with urinary bilharziasis. They were of the same age group as Group I but were free from disease of the joints, heart, or liver. All had terminal haematuria and living ova of Schistosoma haematobium were found in the urine.

\section{GROUP III}

32 children with both urinary bilharziasis and rheumatic polyarthritis with a definite cardiac lesion.

GROUP IV

18 children with amoebiasis, eight with enteric fever, and six with giardiasis.
The presence of rheumatoid factor was determined by Greenbury's modification of the Waaler-Rose sheep cell agglutination test (SCAT) (Greenbury, 1960). The test was considered positive if the titre was $1: 16$ or over.

The latex-fixation test (LFT) was also performed in all cases and results were compared with those of the SCAT. The data were analysed for each group and were compared with the data obtained from a normal control group (Abdin, Abul Fadl, and El-Fil, 1970) and from a group with juvenile rheumatoid arthritis (Abdin and others, 1970).

\section{Results}

The results are summarized in Table I, where they are also compared with those from a control group of 104 healthy children (Abdin and others, 1970). The high incidence of SCAT positivity in rheumatic fever patients as well as in cases of bilharziasis when compared with the control series is striking.

The incidence of rheumatoid factor in rheumatic fever, bilharziasis and juvenile rheumatoid arthritis is compared in Table II, and SCAT titres in these conditions are compared in Table III. The incidence of the different titres is similar in the three groups; a titre exceeding 1:64 occurred in only three patients.

Table II Incidence of positive SCAT in juvenile rheumatoid arthritis as obtained by different authors compared with that found in rheumatic fever and bilharziasis

\section{Diagnosis}

Percentage positive SCAT

\begin{tabular}{ll}
\hline $\begin{array}{l}\text { Juvenile rheumatoid arthritis } \\
\text { (Scott, 1952) }\end{array}$ & 13 \\
$\begin{array}{l}\text { Juvenile rheumatoid arthritis } \\
\text { (Kellgren and Ball, 1959) } \\
\begin{array}{l}\text { Juvenile rheumatoid arthritis } \\
\text { (Abdin and others, 1970) }\end{array}\end{array}$ & 40 \\
\hline Rheumatic fever & $50 \cdot 5$ \\
\hline Bilharziasis & $10 \cdot 6$ \\
\hline
\end{tabular}


Table I Incidence of positive SCAT in cases of rheumatic fever, parasitic infestations, and controls

\begin{tabular}{|c|c|c|c|c|}
\hline \multirow[t]{2}{*}{ Group } & \multirow[t]{2}{*}{ Diagnosis } & \multirow[t]{2}{*}{ No. of cases } & \multicolumn{2}{|c|}{ Positive SCAT } \\
\hline & & & No. & per cent. \\
\hline \multirow{2}{*}{$\begin{array}{l}\text { IA } \\
\mathbf{I B}\end{array}$} & \multirow{2}{*}{$\begin{array}{l}\text { Rheumatic fever } \\
\text { Quiescent rheumatic } \\
\text { heart disease }\end{array}$} & 142 & 15 & $10 \cdot 6$ \\
\hline & & 27 & 0 & $\mathbf{0}$ \\
\hline II & Bilharziasis & 64 & 8 & $12 \cdot 5$ \\
\hline III & $\begin{array}{l}\text { Bilharziasis }+ \\
\text { rheumatic fever }\end{array}$ & 32 & 6 & $18 \cdot 8$ \\
\hline IV & $\begin{array}{l}\text { Amoebiasis } \\
\text { Enteric fever } \\
\text { Giardiasis }\end{array}$ & $\begin{array}{r}18 \\
8 \\
6\end{array}$ & $\begin{array}{l}\mathbf{0} \\
\mathbf{0} \\
\mathbf{0}\end{array}$ & $\begin{array}{l}\mathbf{0} \\
\mathbf{0} \\
\mathbf{0}\end{array}$ \\
\hline Healthy controls & & 104 & 1 & 0.9 \\
\hline
\end{tabular}

Table III SCAT titres in patients with positive tests

\begin{tabular}{|c|c|c|c|c|c|c|c|c|c|}
\hline \multirow[t]{3}{*}{ No. of cases } & \multirow[t]{3}{*}{ Diagnosis } & \multicolumn{8}{|c|}{$S C A T$ titres } \\
\hline & & \multicolumn{2}{|c|}{$1: 16$} & \multicolumn{2}{|c|}{$1: 32$} & \multicolumn{2}{|c|}{$1: 64$} & \multicolumn{2}{|c|}{$1: 128$} \\
\hline & & No. & Per cent. & No. & Per cent. & No. & Per cent. & No. & Per cent. \\
\hline 52 & $\begin{array}{l}\text { Juvenile rheumatoid arthritis } \\
\text { (Abdin and others, 1970) }\end{array}$ & 25 & 48 & 18 & 34 & 7 & 14 & 2 & 4 \\
\hline 15 & Rheumatic fever & 6 & 40 & 6 & 40 & 2 & 14 & 1 & 6 \\
\hline 8 & Bilharziasis & 4 & 50 & 3 & 38 & 1 & 12 & 0 & 0 \\
\hline
\end{tabular}

Table IV illustrates the relationship between the results of the SCAT and LFT. The two tests are largely in agreement. In a minority of cases there is a positive LFT and a negative SCAT, but the reverse did not occur.

\section{Discussion}

The occurrence of rheumatoid factor in both rheumatic fever and bilharziasis is of interest with regard to the specificity and differential value of the SCAT. The incidence is almost as high as the 13 per cent. positive found in juvenile rheumatoid arthritis by Scott (1952).

In our own studies of juvenile rheumatoid arthritis, however (Abdin and others, 1970), which were conducted mainly on children over 6 years of age (a similar age to that of most cases of rheumatic fever), the incidence of positive lests was over 50

Table IV Relationship between SCAT and LFT (numbers of test sera differ from numbers of patients because some patients were tested more than once)

\begin{tabular}{|c|c|c|c|c|c|c|c|c|c|}
\hline \multirow[t]{2}{*}{ No. of sera } & \multirow[t]{2}{*}{ Diagnosis } & \multicolumn{2}{|c|}{$\begin{array}{l}S C A T+ \\
L F T+\end{array}$} & \multicolumn{2}{|c|}{$\begin{array}{l}S C A T- \\
L F T-\end{array}$} & \multicolumn{2}{|c|}{$\begin{array}{l}S C A T+ \\
L F T-\end{array}$} & \multicolumn{2}{|c|}{$\begin{array}{l}S C A T- \\
L F T+\end{array}$} \\
\hline & & No. & Per cent. & No. & Per cent. & No. & Per cent. & No. & Per cent. \\
\hline 118 & Juvenile rheumatoid arthritis & 63 & $53 \cdot 4$ & 45 & $38 \cdot 1$ & 0 & 0 & 10 & $8 \cdot 5$ \\
\hline 201 & Rheumatic fever & 21 & $10 \cdot 4$ & 176 & $87 \cdot 6$ & $\mathbf{0}$ & $\mathbf{0}$ & 4 & $2 \cdot 0$ \\
\hline 64 & Bilharziasis & 8 & $12 \cdot 5$ & 53 & $82 \cdot 8$ & 0 & 0 & 3 & $4 \cdot 7$ \\
\hline 32 & Other diseases & 0 & 0 & 32 & $100 \cdot 0$ & 0 & 0 & 0 & 0 \\
\hline 104 & Normal controls & 1 & 0.9 & 102 & $98 \cdot 1$ & 0 & 0 & 1 & 0.9 \\
\hline
\end{tabular}


per cent. Twelve of the fifteen cases of rheumatic fever with a positive SCAT were girls between 12 and 16 years of age, and the possibility of rheumatoid arthritis coincident with established rheumatic valve lesions cannot be ruled out conclusively. All the fifteen cases of rheumatic heart disease with positive SCAT were followed-up for long periods, and showed no radiological erosions, continuing joint involvement, or residual limitation of joint movement.

Similarly the interpretation of the positive SCAT encountered in our cases of bilharziasis is far from obvious. Have these patients a special tendency to rheumatoid disease (of which there was no clinical evidence) or does Schistosoma haematobium possess an inherent power of stimulating the production of the same macroglobulin as that occurring in rheumatoid arthritis?

The comparison drawn between the LFT and SCAT showed agreement in about 90 per cent. of cases. This confirms that the relatively simple LFT has its place as a screening test in rheumatoid arthritis.

\section{Summary and conclusions}

Tests for rheumatoid factor were carried out in 142 children with rheumatic fever, 64 with bilharziasis, eighteen with amoebiasis, eight with enteric fever, and six with giardiasis. The results were compared with those obtained in 103 children with juvenile rheumatoid arthritis and in a control series of 104 normal children.

The incidence of positive SCAT was 10.6 per cent. in the rheumatic fever series and $12 \cdot 5$ per cent. in the bilharziasis series. There was a clear difference from the control series where only 0.9 per cent. of cases showed a positive SCAT. These figures were, however, much lower than that of 50.5 per cent. obtained by us in a series of cases of juvenile rheumatoid arthritis. Though the explanation of the raised SCAT in rheumatic fever and bilharziasis is not clear, the finding is relevant to the differential diagnosis between rheumatic fever and rheumatoid arthritis, and also to the diagnosis of arthritis and arthralgia in children with bilharziasis. It is clear that in Egyptian children rheumatic heart disease associated with arthritis and also bilharziasis can both be associated with a positive SCAT, and a positive test should thus be interpreted with caution.

\section{References}

Abdin, Z. H., Abul Fadl, M. A. M., And El-Fil, S. (1970) Pak. pediat. J., 1, 39.

BARTFELD, H. (1960) Ann. intern. Med., 52, 1059 (Incidence and significance of seropositive tests for the rheumatoid factor in nonrheumatoid diseases).

Black, A., Goldin, M., Poske, R. M., AND Malmed, L. (1959) Arthr. and Rheum., 2, 99 (Differentiation between rheumatoid arthritis and systemic lupus erythematosus by the sheep cell agglutination test).

Bywaters, E. G. L., Carter, M. E., AND Scott, F. E. T. (1959) Ann. rheum. Dis., 18, 225 (Differential agglutination titre in juvenile rheumatoid arthritis).

Dison, A. ST. J. (1960) Ibid., 19, 209 (Rheumatoid arthritis with negative serological reactions).

Greenbury, C. L. (1960) J. clin. Path., 13, 325 (Comparison of the Rose-Waaler, latex-fixation, 'RA-test', and bentonite flocculation tests).

Hill, A., AND Greenbury, C. L. (1965) 'Clinical interpretation of serological tests in rheumatoid arthritis', in 'Progress in Clinical Rheumatology', ed. A. St. J. Dixon, p. 42. Churchill, London.

Jones, T. DuCKetr (1955) Mod. Conc. cardiovasc. Dis., 24, 291 (Jones criteria (modified) for guidance in the diagnosis of rheumatic fever: Report of the Committee on Standards and Criteria for Programs of Care of the Council of Rheumatic Fever of the American Heart Association).

Kellgren, J. H., AND Ball, J. (1959) Brit. med. J., 1, 523 (Clinical significance of the rheumatoid serum factor).

ScotT, F. E. T. (1952) Lancet, 1, 392 (The differential sheep cell agglutination test in rheumatoid arthritis).

ZIFF, M. (1957) J. chron. Dis., 5, 644 (The agglutination reaction in rheumatoid arthritis). 